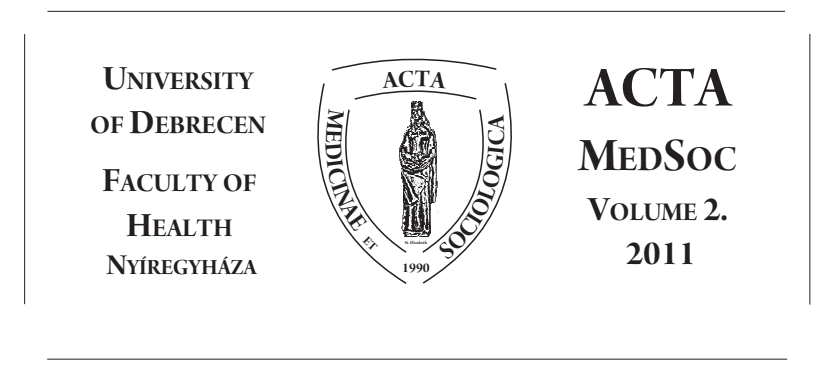

\title{
Ápolók pályaelhagyásának és migrációjának további statisztikai elemzése
}

\author{
Takács Péter - Siket Adrienn \\ Debreceni Egyetem, Egészségügyi Kar
}

\begin{abstract}
Further statistical analysis of the migration and leaving the profession of nurses. In this paper we have focused on the migration of nurses, which has assumed international dimensions. We first present a wide-ranging study (NEXT-survey of the European Union), which is based on our research. Subsequently, we describe our previous studies on this topic. These studies were continued in two phases $(3+1$ sections). The Exploratory Factor Analysis (EFA) provides for a four-factor model. The factors: satisfaction with the current conditions; Vocation; The idea of working abroad; Related expectation (to working abroad). The last part of the essay describes the research, which explores close relationship NEXT-survey and our research. The Confirmatory Factor Analysis (CFA) certifying that the applied survey is closely related to the original questionnaire NEXT. They are comparable, the results are matched to the NEXT-survey. Finally, it must be said (again) that it is essential to develop a national model for health careers to improve the current situation.
\end{abstract}

Keywords: nursing migration, NEXT-survey, Exploratory and Confirmatory Factor Analysis

DOI: $10.19055 / \mathrm{ams} .2011 .2 / 2 / 3$

Dolgozatunk témája az ápolók migrációja, amely a 21. századra nemzetközi méreteket öltött. Elsóként azt az Európai Unióban folytatott széles körú vizsgálatot mutatjuk be (NEXT-felmérés), amelynek módszertani megközelítését saját kutatásaink alapjául használtunk. Ezt követően saját, korábbi eredményeinket ismer- 
tetjük. Ezek a kutatások két fázisban, összesen négy szakaszban $(3+1)$ folytak. A feltáró faktorelemzés (EFA) négyfaktoros modell kialakítását irányozza elő. A faktorok a jelenlegi körülményekkel való elégedettséget, a hivatástudatot, a külföldi munkavállalás szándékát és az ehhez kapcsolódó elvárásokat tükrözik. A dolgozat utolsó része azokat a kutatásokat mutatja be, amelyek a NEXT-felmérés és az általunk elvégzett elemzések még szorosabb kapcsolatát tárják fel. Az ellenốrzô faktorelemzés (CFA) igazolja, hogy az alkalmazott kérdőív, mint mérési eszköz az eredeti NEXT kérdôívhez szorosan kapcsolódik. Eredményeink így illeszthetők a NEXT vizsgálathoz, összehasonlíthatók azokkal. Az elemzés értékeléseként nekünk is le kell szögeznünk, hogy a kialakult helyzet javítására elengedhetetlen az országos szintú életpálya-modellek kidolgozása. ${ }^{1}$

Kulcsszavak: ápolói migráció, NEXT-felmérés, feltáró- és ellenőrző faktoranalízis

Lektor: Dr. Betlehem József, egyetemi docens, dékán, Pécsi Tudományegyetem, Egészségtudományi Kar

\section{Bevezetés}

Az ápolók migrációja a 21. századra nemzetközi méreteket öltött. Néhány országban komoly gondolat okozhatnak ezek a folyamatok. Részletesebben, országos és nemzetközi szinteken a [1-10] forrásokban olvashatunk a problémakörról. Ezeket az írásokat összefoglalva leszögezhetjük, hogy halaszthatatlan a helyzet nemzetközi és hazai értékelése, áttekintése. Szükség van az országok közötti tapasztalatok cseréjére, és elengedhetetlen országos szintú modellek (életpálya modell) szabályozások, rendeletek kidolgozása - nemzetközi egyeztetéssel.

A továbbiakban azt az Európai Unióban folytatott széles körü vizsgálatot mutatjuk be (NEXT-felmérés), amelynek módszertani megközelítését saját kutatásaink alapjául használtunk. Ezt követően saját, korábbi eredményeinket ismertetjük. A dolgozat utolsó része azokat az új eredményeket mutatja be, amelyek a NEXTfelmérés és az általunk elvégzett kutatások még szorosabb kapcsolatát tárják fel.

\section{A NEXT-felmérés az Európai Unióban}

A NEXT-felmérés (Nurses Early Exit Study - Ápolók Korai Pályaelhagyása) [11] célja az ápolói pályával kapcsolatban megfigyelhetô megnövekedett pályaelhagyás és migráció okainak, körülményeinek és következményeinek feltárása az Európai Unión belül. A vizsgálat szoros kapcsolatba hozható a bevezetóben említett világméretû migrációs tendenciákkal.

A felmérés az Európai Unió által finanszírozott projekt (QLK6-CT-2001-00475),

\footnotetext{
${ }^{1}$ A dolgozat a 2010.09.09-10-i nyíregyházi ápolói konferencián („Az ápolás 100 évvel Florence Nightingale után") elhangzott előadás szakmailag bővített változata.
} 
amely párhuzamosan folyt 10 európai országban (Belgium, Finnország, Franciaország, Németország, Nagy Britannia, Olaszország, Hollandia, Lengyelország, Svédország, Szlovákia; később Norvégia kapcsolt tagként csatlakozott). Több mint negyven kutató, tizennégy kutatóintézet volt tagja a kutatócsoportnak. A kutatócsoportot gyakorló ápolók, kutató-ápolók, egészségügyi szakemberek, orvosok, pszichológusok, szociológusok és statisztikusok alkották. Elmondható, hogy a kutatás számos szakterület ve-zető szakembereit fogta egybe.

A felmérés legnagyobb, adatgyújtési része 2002 februárjában indult, és 2005 júniusáig tartott. Az elôkészítô munkák már a 2000-es évben elkezdôdtek, a projekt utómunkálatai, a publikációs tevékenység és az eredményekkel kapcsolatos elemzések még napjainkig folynak.

A résztvevố országokban a NEXT-kutatócsoport elsô körben keresztmetszeti felmérést végzett, 56.406 fô bevonásával. A későbbiekben 18.796 ápoló bevonásával longitudinális elemzésre is sor került. Összesen 66.236 kérdőív és 220 szervezeti át-tekintő lista került kitöltésre és visszaküldésre az adatfelvételi periódusban. [11]

\section{A NEXT-felmérés elméleti modellje}

A NEXT-felmérés a projekt definiálási fázisában a következó faktorokat definiálta az ápolói pálya elhagyása és a pályaelhagyás okainak feltárására (1. ábra - az eredeti NEXT-jelentés ábrája).

Az 1. pontban a munkahelyi környezet (WORK), a munka tartalmát; a 2. pontban a személyes helyzet (PRIVATE) szerepét rögzíti a felmérés. A 4 . pont a személyes erő-forrásokat (INDIVIDUAL RESOURCES - beleértve az egészségi állapot, kor, stb.) fogja egybe. Az 1., 2. és 4. részeket érő hatásokat írja le a 3. rész (EXPOSURE). Ezekrôl a részekról feltételezi a kutatás, hogy vagy hirtelen élményként, vagy összegezve, ku-mulálódva fejtik ki hatásukat az 1., 2., 4. elemekre. Mindezen hatásokhoz kapcsolód-nak azok a társadalmi-, gazdasági alternatívák, amelyeket az 5. rész ír le. A modell-ben az 1.-5. pontok összetett eredménye a 6 . rész, amely a pályaelhagyás, a migráció, vagy a pályán-maradás alternatívái közötti döntési motivációt jelöli.

\section{Az adatfelvétel lefolytatása}

A NEXT-felmérés adatfelvételi modulja 2002 ószén indult, ekkor közel hetvenhétezer ápoló kapta meg az alap-kérdőívet (BQ, Basic questionnaire, alap kérdőív). Ez a felmérés keresztmetszeti része. A vizsgálat folytatásaként a következô egyéves perióduson belül a munkahelyükrôl távozó (pályaelhagyás, belső/külsô migráció) ápolók egy újabb kérdőívet kaptak (LQ, leavers' questionnarie, pályaelhagyók kérdôíve). Egy év elteltével, 2003 ószén a munkahelyükön maradók szintén újabb kérdôívet kaptak (BQ12, 12 month follow up questionnarie, pályán maradók kont- 


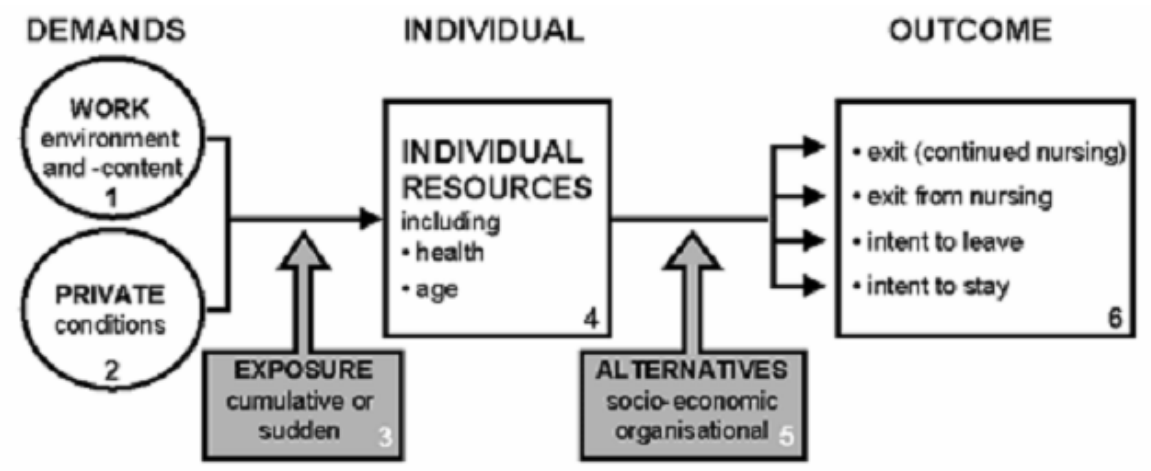

1. ábra. A NEXT-felmérés modellje. Ábramagyarázat: DEMANDS: IGÉNYEK; INDIVIDUAL: EGYÉNI; OUTCOME: VÉGEREDMÉNY, FOLYOMÁNY. 1. WORK environment and -content: MUNKAVÉGZÉSI körülmények és a munka tartalma, összetétele; 2. PRIVATE conditions: EGYÉNI feltételek; 3. EXPOSURE cumulative or sudden: HATÁSOK összegződő és hirtelen; 4. INDIVIDUAL RESOURCES including health and age: EGYÉNI FORRÁSOK ÉS LEHETỐSÉGEK beleértve az egyéni egészségi állapotot és az életkort; 5. ALTERNATIVES socio- economic and organisational: ALTERNETÍVÁK szociális, gazdasági és szervezeti; 6 . OUTCOME exit (continued nursing), exit from nursing, intent to leave, intent to stay: VÉGEREDMÉNY kilépés (ápolóként dolgozik tovább), kilépés az ápolói szakmából, a pályaelhagyás szándéka, a pályánmaradás szándéka.

roll kérdőíve). A munkájukat a vizsgálati évben elhagyók a kilépés időpontjától számított egy év elteltével szintén újabb kérdőívet kaptak (LQ12, 12 month leavers questionnarie, pályaelhagyók kontroll kérdőíve). Így a felmérési idôszak 2004 ôszéig tartott. 2002 augusztusában a felmérésben részt vevô intézmények külön kérdőívet kaptak, helyzetük áttekintése céljából (OA, organisation analysis, szervezeti elemzés kérdőíve). Mindezeket a 2. ábra szemlélteti. [11]

\section{A NEXT-felmérés eredményei}

A felmérés eredményei egy összefoglaló kötetben [11] jelentek meg, amelyet az összes résztvevô közremúködésével alakítottak ki. Ez a kiadvány részletesen ismerteti a fentebb vázolt modell elemeit, majd a felmérés országos és európai szintú vizsgálati eredményei következnek. Mindemellett kilencvennél több tudományos közlemény, százhúsznál több nemzetközi és nemzeti szinteken elhangzott előadás foglalkozott a felméréssel. Nyolcvannál több regionális és nemzeti konferencián jelent meg kimutathatóan a vizsgálat.

Az elért eredmények olyan kutatási alapot jelentenek az ápolói pályaelhagyásés migráció területén, amelyek napjainkban és a jövőben is sok kutatás kiindulópontjául, összehasonlítási standardjául szolgál.

Itt nincs módunk - és nem is célunk - a kutatás eredményeinek további rész- 


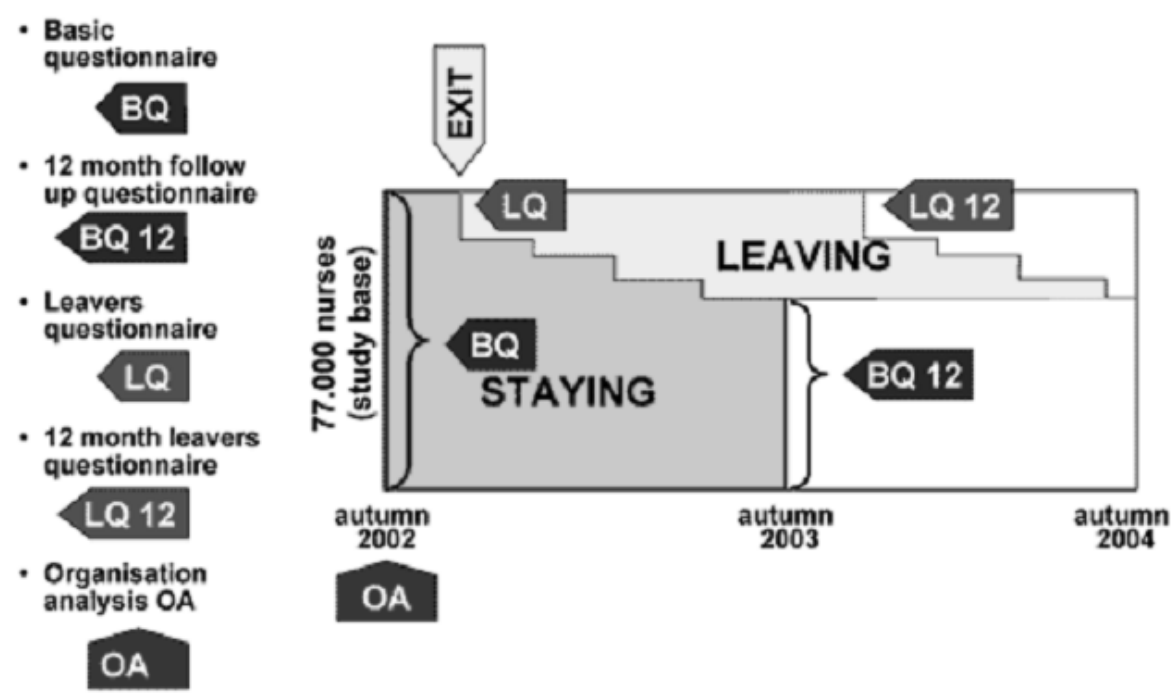

2. ábra. A NEXT-felmérés idóbeli lefolyása. [11] Ábramagyarázat: felmérés idôszaka 2002 ősze, 2003 ősze, 2004 ôsze; mintaelemszám: 77.000 ápoló - kiinduló létszám. BQ Basic questionnarie: Alap kérdőív; BQ12 12 month follow up questionnarie: 12 hónap múlva esedékes követéses kérdőív; LQ Leavers questionnarie: a munkahelyet elhagyók kérdôíve; LQ12 12 month leavers questionnarie: a munkahelyet elhagyók 12 hónap múlva esedékes követéses kérdőíve; OA Organisation analysis: szervezeti áttekintő kérdôív. EXIT: kilépés a munkahelyről; STAYING: pályánmaradók; LEAVING: munkahelyet elhagyók (szakmában és szakmán kívül elhelyezkedôk)

letes ismertetése, az érdeklődók számára biztos kiindulási pontként ajánlhatjuk a NEXT-felmérés honlapját: www.next-study.net. Az oldalon folyamatosan jelennek meg a NEXT-felméréssel kapcsolatos újabb és újabb eredmények.

\section{A NEXT-felmérés és a magyar kutatási eredmények}

Magyarország nem vett részt a NEXT-felmérésben, de több kutatási projekt is végzett hasonló irányú kisebb, nagyobb volumenú felmérést. [4-10]

Kutatócsoportunk 2006-ban tûzte maga elé azt a célt, hogy az ápolói pályaelhagyást és migrációt vizsgálja Magyarországon, kiegészítve az addigi magyar vonatkozású vizsgálatokat.

Sajnos - hasonlóan a többi magyar felméréshez - technikai-, gazdasági-, és idôkorlátok miatt nekünk sem volt módunk megismételni a teljes NEXT-felmérést hazánkban. A korlátok figyelembe vételével úgy döntöttünk, hogy vizsgálatainkban a hangsúlyt a migráció kérdéskörére helyezzük. Vizsgálatunk keresztmetszeti jellegû felmérés volt. A kérdőív összeállítását ápolási szakemberek bevonásával, két 
ütemben végeztük (mutatók). A kérdőív véglegesítése egy próbafelmérést követően (15 fő) történt. A végleges kérdőív 37 zárt kérdést foglalt magába, négy fơ részre bonthatóan:

- Demográfiai és szociológiai alapadatok.

- Tanulmányokat folytató ápolóhallgatók kérdései.

- Munkában álló, dolgozó ápolók kérdései.

- Közös kérdések.

$\mathrm{Az}$ adatfelvétel több részben (két fázis, összesen négy szakasz) történt (3. ábra)

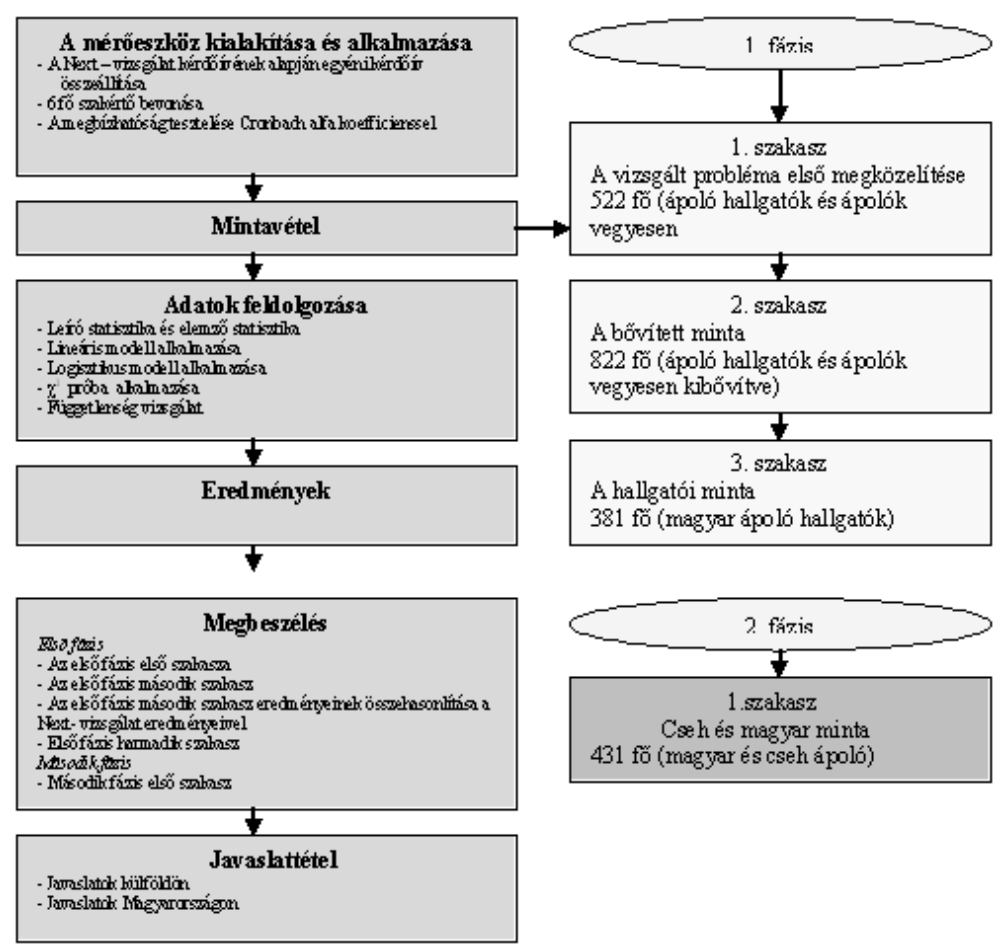

3. ábra. Felmérésünk ütemezése 2006 és 2010 között.

Az elsô fázis elsố szakaszában elôször három helyszínen (Debrecen, Nyíregyháza, Pécs), 2006-ban alkalmaztuk a kérdőívet. A mintanagyság ebben a szakaszban 522 fố volt [9]. Az eredmények értékelése során világossá vált, hogy a hallgatókra vonatkozó regressziós modellek csak a vonatkozó mintanagyság bóvítésével alakíthatók ki. Ezt sikerült elérnünk a második szakaszban, egy nagyobb, nyíregyházi ápolókat és ápolóhallgatókat tartalmazó minta bevonásával. Ebben a szakaszban elért 
mintanagyság 822 före növekedett. A magyarországi múködési nyilvántartásban szereplő 86.160 fôs egészségügyi szakdolgozó számát vettük az ápolói alapsokaságnak. Mintánkban (822 fôs minta esetében) 441 ápoló került be, ami 0.51 százalékos arányt jelent [12].

A harmadik szakaszban az ápolóképzés viszonyait elemeztük. Az elsó két szakasz eredményei közül szürtük ki a hallgatói mintát, valamint a korábbi felmérések helyszínén újabb kérdőíveket töltettünk ki. A mintanagyság ebben az esetben 381 fố volt [13].

A kutatás folytatásaként a második szakasz hallgatói anyagát hasonlítottuk össze egy cseh mintával. Célunk kutatási eredményeink kiterjesztése volt. Az összehasonlítás eredményeként kialakított modell fő eredménye a magyar viszonyok jövőbeni előrejelzésének lehetősége [14].

Kutatásunk során kezdetektôl fogva törekedtünk a reprezentativitás elérésére, de a hivatalos források elemzése során arra jutottunk, hogy a többféle nyilvántartás (Tanulmányi Osztályok, EEKH Alap és Múködési Nyilvántartás, KSH adatbázis) néhol egymásnak ellentmondó adatokat tartalmaznak. Ennek egyik okaként sorolhatjuk fel a különböző fogalmakhoz kapcsolt adatgyújtéseket, amelyeket különböző intézményi hatáskörökben végeztek (fóiskolai oklevelet szerzett ápoló, diplomás ápoló, múködési nyilvántartás, alapnyilvántartás, stb.).

Vizsgálatunk egyik pozitív vonásának, a reprezentativitás közelítésének tekintjük azt, hogy összevethetjük a KSH 2008-as adatai [15] felmérésünkkel. A vizsgált minta és az országos eloszlás adatai hasonló arányokat mutatnak. A betöltött teljes munkaidős és időszakos állások száma a KSH szerint 92.090 fő. Ebból az ápolók létszáma (az alkalmazottak és a vállalkozók együttesen) 49.230 fó. Végzettségi szinten-ként: felsófokú végzettséggel rendelkezik (diplomás ápoló) 3.716 fő (7,5\%); középfokú végzettségú (ált. ápoló, ápoló, egyéb szakápoló) 43.326 fô (88,0\%); alapfokú végzettségú 2.188 fő (4,4\%). Vizsgált mintánk esetén: (813 fő válaszolt erre a kérdésre a 828 fôs mintából): felsőfokú végzettséggel rendelkezik, tehát diplomás ápoló 57 fő (7,0\%), illetve egyetemi okleveles ápolói végzettségú 5 fố $(0,6 \%)$; középfokú végzettségú (ált. ápoló, OKJ ápoló, egyéb szakápoló) 616 fő (75,8\%); alapfokú végzettségú: (segédápoló) 32 fố (3,9\%); érettségivel rendelkezik: 103 fő $(12,6 \%$ ).

\section{A magyar vizsgálat további statisztikai elemzése}

Az elókészítési, adatelemzési folyamat közben több esetben is felmerült bennünk az, hogy mindenképpen szükséges saját vizsgálataink és a NEXT-felmérés összevetése. Most ezen kérdések és eredmények teljesebbé tétele a célunk.

Az adatok elemzési szintjén túl a statisztika módot ad arra, hogy magukat a vizsgálati eszközöket, az alkalmazott kérdőíveket is tanulmányozzuk. Ezen vizsgálatok egyik legerôsebb módszertani fejezete az általunk is alkalmazott faktorelemzés.

A módszer lényege nem az adatok közvetlen vizsgálata, hanem az adatokon 
keresztül az alkalmazott kérdések közötti struktúra feltárása. Az egyes kérdések, kérdéscsoportok közötti kapcsolatok feltárása révén módunkban áll az összetartozó kérdéseket összevonni, sok esetben új megközelítést adni a kutatásnak. A kérdések összevonásával kialakult új változókat faktoroknak szokták nevezni.

Két fő módszertani irányzat alakult ki a faktorelemzésen belül. Az elsô, és viszonylag gyakran alkalmazott módszer a Feltáró faktorelemzés (Exploratory Factor Analysis - EFA). Ennek módszernek a célja a kérdéshalmazban lévő struktúra feltárása. Ilyenkor nincs elsődleges elméleti háttér a faktorok kialakításakor. A ritkábban használt másik módszer az Ellenôrző faktorelemzés (Confirmatory Factor Analysis). Ebben az esetben a kutató egy meglévố modell faktoraiból indul ki, és annak helyességét, az adatokból tükröződő struktúrához való illeszkedés jóságát vizsgálja. [16][17]

Munkánk során mindkét említett módszertani megközelítést alkalmaztuk. A Feltáró faktorelemzés az SPSS programcsomag 15-ös verziójának felhasználásával, az ellenőrzô faktorelemzés pedig a Lisrel for Windows 8.0 verzióval készült.

\section{Feltáró faktorelemzés}

A kérdőív 52 kérdéséból 17 kérdést válogattunk be az elemzésbe, azokat a kérdéseket, amelyek a kutatás fó irányát, a pályaelhagyást és a migrációt vizsgálták. A használt minta a 2007-ben felmért 822 fôs minta volt.

A modell faktorainak számát a Kaiser-kritérium, a „könyök-ábra”, a KMO-érték, és a szericitásra alkalmazott Bartlett teszt alapján határoztuk meg.

A Kaiser nevével jelzett mutatószám a leggyakrabban alkalmazott döntési mutató a faktorok számát illetően. A vizsgálatok során kialakított faktorok közül azokat fogadjuk el, amelynek sajátértéke 1-nél nagyobb. Esetünkben a mutató a négy faktort tartalmazó modell kialakítását irányozta eloo. Szintén a négyfaktoros modell kialakítása mellett szól a „könyök-ábra”. Itt szintén a sajátértékek az iránymutatók. Pontosabbnak tekintett mutatószám a KMO érték, amely 0 és 1 között mozog. A modell annál megbízhatóbb, minél közelebb áll a KMO mutató 1-hez. A 0,6 értéket határpontként szokás tekinteni; ez alatti KMO értékekkel rendelkezô modellt nem szokás elfogadni. Esetünkben a négyfaktoros modell KMO értéke 0,777. A Bartlett teszt nullhipotézise a vizsgálatok során kialakított korreláció-mátrix egységmátrix voltának vizsgálatára vonatkozik, vagyis a bevont változók korrelálatlanok. A négyfaktoros modell esetén a teszt szignifikancia értéke Sig. =0,000, ami a nullhipotézis elvetését, vagyis a korrelálatlanság feladását jelenti. A modellben szereplő változók korrelálnak, összefüggnek.

A fenti mutatószámokra hivatkozva a négy faktort tartalmazó modell mellett döntöttünk. A rotált faktormátrixot a 4. ábrán mutatjuk be. A táblázatban kiemelve láthatók az egyes összetartozóknak ítélt kérdések.

Az egyes faktorok értelmezése, interpretációja a következô lehet: F1 - ELÉGEDETTSÉG (Satisfaction now) = jelenlegi munkakörülményekkel való elégedettség F2 - HIVATÁS (Vocation) = hivatástudat F3 - KÜLFÖLDI MUNKAVÁLLALÁS 


\begin{tabular}{|c|c|c|c|c|}
\hline & \multicolumn{4}{|c|}{ Component } \\
\hline & $\mathrm{F} 1$ & $\mathrm{~F} 2$ & F3 & $\mathrm{F} 4$ \\
\hline külföldön dolgozik tovább az ápolásban, gondolt arra kerd33 &,- 181 & 225 &,- 007 & 712 \\
\hline $\begin{array}{l}\text { külföldi munkát közvetítő irodával kapcsolatba lépett már } \\
\text { kerd34 }\end{array}$ &,- 030 & 116 & 190 & ,716 \\
\hline $\begin{array}{l}\text { anyagi helyzete, megbecsülése javulása fontos külföldi mun- } \\
\text { kavégzésnél kerd35a }\end{array}$ &,- 039 &, 614 &,- 129 & 238 \\
\hline $\begin{array}{l}\text { MUNKAKÖRÜLMÉNYEI JAVULÁSA FONTOS KÜLFÖLDI MUNKAVÉGZÉSNÉL } \\
\text { KERD35B }\end{array}$ & 001 &, 807 &,- 164 &,- 025 \\
\hline $\begin{array}{l}\text { JOBB TANULÁSI, FEJLÖDÉSI LEHETÓSÉG FONTOS KÜLFÖLDI } \\
\text { MUNKAVÉGZÉSNÉL KERD35c }\end{array}$ &,- 106 & 761 & 140 &,- 073 \\
\hline $\begin{array}{l}\text { KIEMELKEDÉS A JELENLEGI KÁTYÚBÓL FONTOS KÜLFÖLDI } \\
\text { MUNKAVÉGZÉSNÉL KERD35D }\end{array}$ &,- 078 &, 720 &,- 199 & 137 \\
\hline FIZETÉSSEL ELÉGEDETTSÉG KERD23A & 078 &,- 001 & 620 &,- 183 \\
\hline KOLLÉGÁKKAL ELÉGEDETTSÉG KERD23B &,- 050 &,- 042 & 655 &,- 081 \\
\hline MUNKAKÖRÜLMÉNYEKKEL ELÉGEDETTSÉG KERD 23C &, 238 &,- 188 & 611 &, 050 \\
\hline $\begin{array}{l}\text { MUNKAIDŐ RUGALMASSÁGÁVAL, BEOSZTÁSSAL, TÚLÓRÁK SZÁMÁVAL } \\
\text { ELÉGEDETTSÉG KERD23D }\end{array}$ & 205 &,- 048 &, 632 & 182 \\
\hline $\begin{array}{l}\text { fejlödési lehetőségekkel, továbbképzéssel, karrier elörejutással } \\
\text { elégedettség kerd23e }\end{array}$ &, 244 &,- 139 &, 587 & ,231 \\
\hline $\begin{array}{l}\text { elhagyja az ápolói pályát, de egészségügyön belül helyezkedik } \\
\text { el kerd24 }\end{array}$ &,- 666 & 227 &,- 039 & 178 \\
\hline egészségügyön kívül, más szakmában helyezkedik el kerd25 &,- 768 & 116 &,- 051 & 113 \\
\hline következô egy évben ápolóként dolgozik tovább kred26 &, 664 &,- 009 & ,061 &,- 156 \\
\hline újra az ápolást választaná hivatásnak kerd 28 &, 728 &,- 033 &, 297 &,- 035 \\
\hline ajánlaná másnak az ápolási hivatást kerd29 &, 681 & ,088 & ,201 &, 069 \\
\hline a pálya elhagyására buzdították kerd30 &,- 295 &,- 245 &,- 280 & 0,53 \\
\hline
\end{tabular}

4. ábra. A feltáró faktorelemzés eredménye - Rotált fakormátrix.

EGYÉNI SZÁNDÉKA (The idea of working abroad) = külföldi munkavállaláshoz kapcsolódó közvetlen és közvetett szándékok F4 - ELVÁRT ELÉGEDETTSÉG (Expected satisfaction) = külföldi munkavállaláshoz kapcsolódó elvárt elégedettség.

\section{Ellenôrző faktorelemzés}

A feltáró faktorelemzés során a kialakított négyfaktoros modellból indultunk ki. Az alkalmazott lineáris struktúraelemzô modell a LISREL for Windows programcsomagba beépített SIMPLIS elemzési eljárással készült, a hiányzó adatok figyelembevételével. A vizsgálatok során két modellt alakítottunk ki. Az elsố a tiszta négyfaktoros megközelítést vizsgálta, míg a másodikban a programcsomag futtatása során kapott kimeneti eredmények által javasolt változtatásokat építettük a módosított, újabb modellbe. Itt a faktorokat kialakító kérdések közül egy-egy már nem csak egy faktorhoz csatlakozik. A modelleket a 5. és 6. ábrákon mutatjuk be.

Az ellenőrző faktorelemzés modelljeinek illeszkedését mutató legfőbb számok:

Khí-négyzet érték: A khí-négyzet $\left(\chi^{2}\right)$ érték és a kapcsolódó teszt az illeszkedési vizsgálatok egy klasszikus eszköze. A próba nullhipotézise az, hogy az adatokból eredő és a várható kovariancia-mátrix egyenlő. Nagy khí-négyzet érték és a nullhipotézis elvetése egyben a vizsgált modell elvetését is jelenti. Ekkor az adatok nem tükrözik a kérdések struktúráját. A szakirodalom újabb eredményei szerint a (Jöreskog, 1969, [17]) khí-négyzet érték és a kapcsolódó szignifikancia-érték nem 
minden esetben megbízható, nagyon függ a bevont kérdések számától. Amennyiben lehetséges, újabban más döntési alapot szokás keresni a modellek illeszkedésének értékelésére.

RMSEA-érték: A 'Root Mean Square Error of Approximation' (RMSEA) értéket Steiger és Lind vezette be 1980-ban. A mutató szintén az illeszkedés jóságát méri. Hu és Bentler szerint (1999, [17]) azokban az esetekben, amikor az RMSEA értéke 0,06-hoz közeli, vagy 0,06 alatti (és a CFI és TLI értékek - amennyiben értelmezhetók, nincs hiányzó adat - 0,95-höz közeliek, vagy felettiek) a modell jól illeszkedik, elfo-gadható.

CFI és TLI mutatók: Hiányzó adatok esetén - esetünkben - az érték nem használható. Nem foglalkozunk ezekkel a mutatókkal. További leírás [17]-ben található.

A kialakított modellek fenti mutatói a következók:

1. modell: Degrees of Freedom $=113$ Full Information ML Chi-Square $=427.72(\mathrm{P}$ $=0.0)$ Root Mean Square Error of Approximation $(\mathrm{RMSEA})=0.05390$ Percent Confidence Interval for RMSEA $=(0.048 ; 0.059) \mathrm{P}$-Value for Test of Close Fit $($ RMSEA $<0.05)=0.14$

2. modell: Degrees of Freedom $=96$ Full Information ML Chi-Square $=300.69(\mathrm{P}$ $=0.0)$ Root Mean Square Error of Approximation $(\mathrm{RMSEA})=0.04790$ Percent Confidence Interval for RMSEA $=(0.041 ; 0.053) \mathrm{P}$-Value for Test of Close Fit $($ RMSEA $<0.05)=0.80$

Mindezek alapján kijelenthetjük, hogy a négyfaktoros modell jól illeszkedik az adatok által megjelenített struktúrához. Ez azt jelenti, hogy a kérdôív kérdései a feltáró faktorelemzéssel kialakított négy faktor mentén mérik a migrációs viselkedést.

\section{Összegzés}

A dolgozat elôzô részeiben bemutatásra került az a kutatás, amely kiinduló pontként szolgált számunkra (NEXT-felmérés). Az általunk kialakított kérdőív egy részét feltáró faktorelemzéssel (négyfaktoros modell; $\mathrm{KMO}=0,777$ ); majd ellenőrzésképpen, a modell bővítése érdekében ellenőrző faktorelemzéssel (1. modell RMSEA $=0,053 ; 2$. modell RMSEA=0,047) vizsgáltuk. A feltáró- és ellenőrző faktorelemezés általi eredmények akkor nyernek tényleges értelmezést, ha párhuzamba állítjuk azzal a kiinduló modellel, amely kutatásunk elméleti alapjait szolgáltatta. A NEXT-felmérés 1. ábrán látható modelljéhez illeszthetjük saját kutatásainkat 7. ábra. Az ábrán látható, hogy modellünk a NEXT-modell valamennyi lényeges elemét érinti. A kimeneti oldal mérését modellünkben más kérdésekkel mértük, ami a modellalkotás során meg is jelent.

Összegzésül elmondhatjuk, hogy a dolgozat elején kitûzött céljainkat elértnek tekinthetjük, hiszen sikerült a négyfaktoros modell felállításával igazolni, hogy kutatá-saink kapcsolhatók a NEXT-felméréshez. Az általunk vizsgált populációban 


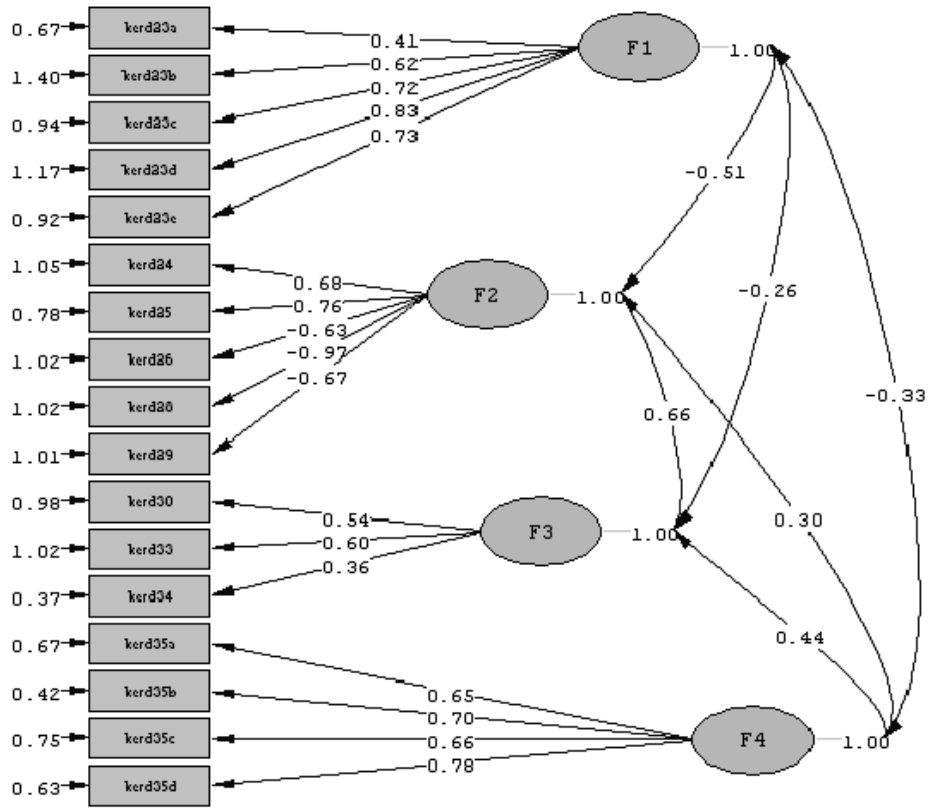

Chi-Square=427.72, df=113, p-value=0.00000, RMSEA=0.053

5. ábra. Az első ellenőrző faktormodell. Ábramagyarázat: kerd33a - kerd35d: a vizsgálatba bevont kérdések; F1 - F4 vizsgált faktorok - kapcsolatok (nyilak) a feltáró elemzés során elért eredmények alapján. F1 - F4 közötti kapcsolatok (nyilak) - faktorok közötti kölcsönhatás, interakció. A nyilakon szereplő együtthatók a modell paramétereit ábrázolják. Minél nagyobb egy együttható értéke, annál nagyobb értékben játszik szerepet az adott kérdés a paraméter kialakítása során.

a pályaelhagyási viszonyok [12-14] illeszkednek azokhoz a trendekhez, amelyeket a NEXT-felmérés is igazolt.

Egy érdekes és figyelemfelkeltô vonása vizsgálatainknak (2. fázis, 1. szakasz) az, hogy megközelítőleg hároméves csúszással a Csehországban kimutatható viszonyok jelennek meg hazánkban [14]. Eszerint erôsödik az a tendencia, hogy a fiatal ápolók egyre többen rendelkeznek olyan nyelvtudással, amely lehetôvé teszi számukra a külföldi munkavállalást, már a tanulmányok közvetlen befejezése után is. Ez újabb hullámát jelzi a migrációnak, a hazai ápolóhiány erôsödésének.

Elemzésünk zárásaként - nekünk is, mint sok más hasonló elemzés szerzőjének le kell szögeznünk, hogy elengedhetetlenné vált a nemzeti szintú, átlátható és megbecsülést biztosító életpálya-modellek kidolgozása az orvosok, az ápolók és más egészségügyi szakmák területén. Ennek feladata és felelőssége az egészségpolitikai vezetőre vár. 


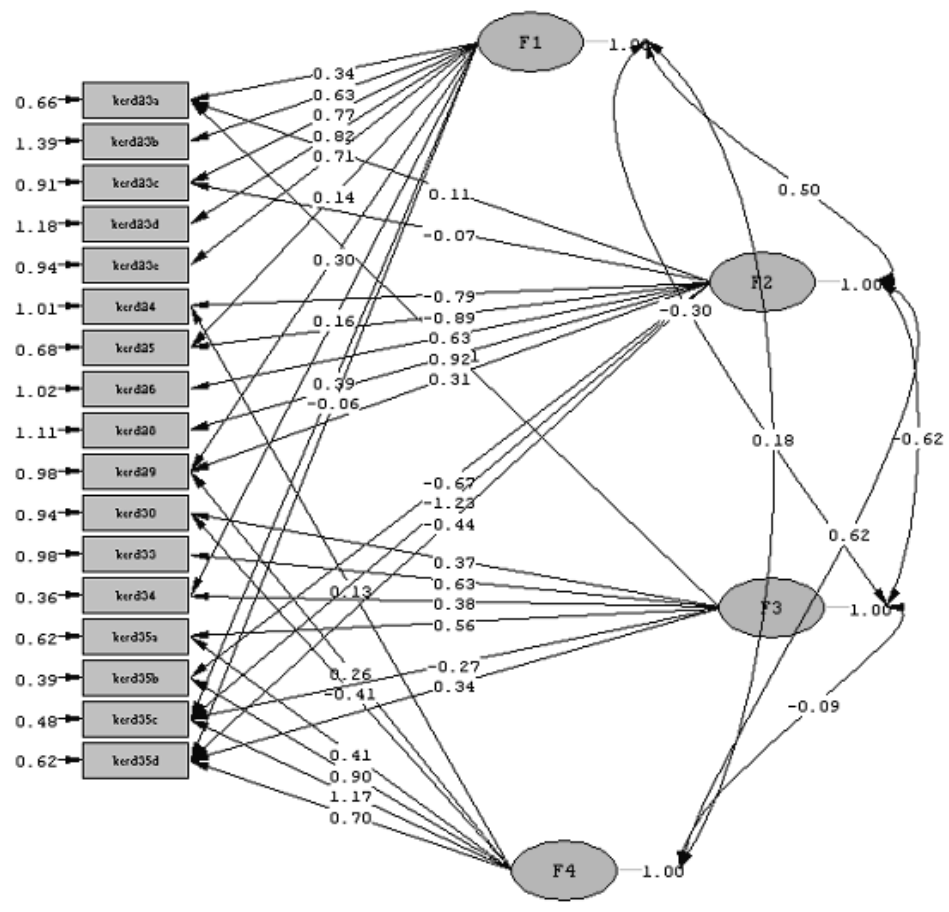

Chi-square=300.69, df=96, P-value=0.00000, RMgEA=0.047

6. ábra. A második ellenốrzô faktormodell. Ábramagyarázat, különbség a 4. ábrához képest: a feltáró elemzés a kérdések egy meghatározott csoportját rendeli egy-egy faktorhoz. A modell elsô futtatása (5. ábra) során a LISREL rendszer javaslatot tesz a faktorokat kialakító tényező́k bővítésére. Így egy-egy kérdés nem csak egy faktorhoz rendelődik. Az ábrán szereplö jelölések, magyarázatok az 5. ábra jelölései szerint értendôk.

\section{Irodalomjegyzék}

1. World Health Organization (2006) The World Health Report 2006 - Working together for health. http://www.who.int/whr/2006/en/index.html

2. World Health Organization Regional Office for Europe. (2006) "Human Resources for Health in the WHO European Region".

http://www.euro.who.int/document/E88365.pdf

3. The Looming Crisis in the Health Workforce: How can OECD countries respond? OECD Health Policy Studies, 2008.

http://www.who.int/hrh/migration/looming_crisis_health_workforce.pdf

4. Frits T.: Hiány az egészségügyben: ahol a globalizáció, az ápolószemélyzet és a migráció találkozik. Egészségügyi Gazdasági Szemle 41. (3), 61-64., 2003. 


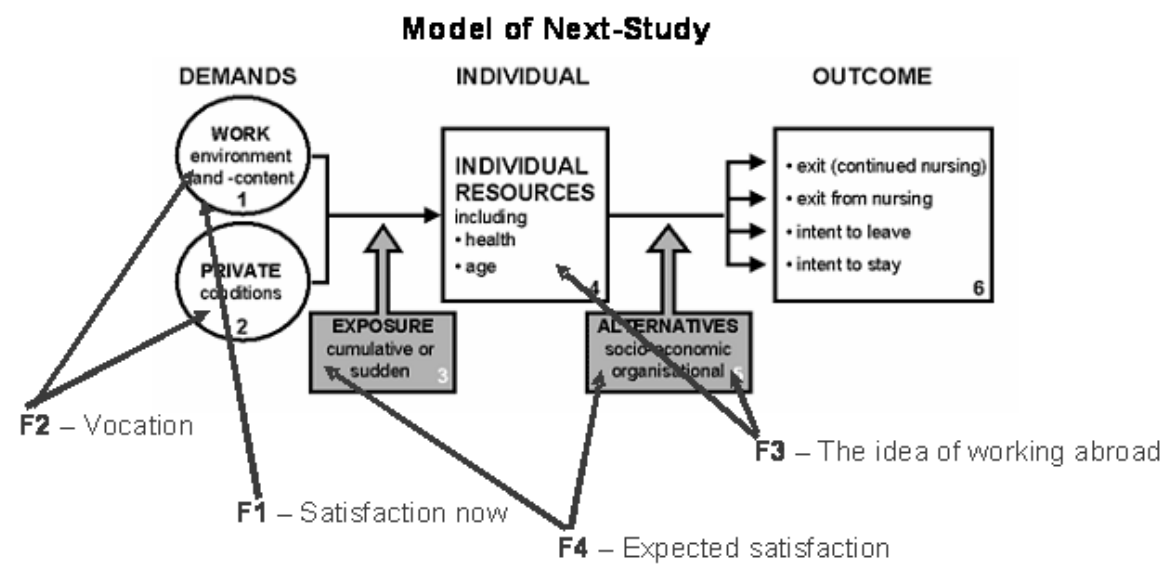

Model of our research

7. ábra. A kutatás és a NEXT-modell összevetése. Ábramagyarázat: Az ábra az 1. ábra bővítése. A kiegészítő elemek (F1-F4 és nyilak) az általunk feltárt faktorok helyét, besorolását mutatják. F1 - ELÉGEDETTSÉG (Satisfaction now) = jelenlegi munkakörülményekkel való elégedettség. F2 - HIVATÁS (Vocation) = hivatástudat. F3 - KÜLFÖLDI MUNKAVÁLLALÁS EGYÉNI SZÁNDÉKA (The idea of working abroad) = külföldi munkavállaláshoz kapcsolódó közvetlen és közvetett szándékok. F4 - ELVÁRT ELÉGEDETTSÉG (Expected satisfaction) = külföldi munkavállaláshoz kapcsolódó elvárt elégedettség.

5. Kovácsné TA., Feith H., Balázs P.:A diplomás ápoló hallgatók pályaválasztási motivációja és pályaelhagyása. Nôvér 17. (6), 9-13., 2004.

6. Zrínyi M.: Előrelépés az ápolói életpályán és az elvándorlás: kritikus kérdések. Az ápolók nemzetközi tanácsának tájékoztatója. Nővér, 17 (1), 2004. 7. Szkrajcsics D.: A migráció jelentősége az ápolók körében. ETInfo, 8 (1),16-19., 2005.

8. Vízvári L.: Ápolók migrációja. ETInfo, 8 (1), 20-21., 2005.

9. Zrínyi M., Zékányné R. I., Tóth H., Siket A.: Idôzített bomba? Pályaválasztás és elvándorlás: Egészségügyi Gazdasági Szemle 45. (1): 39-43., 2007.

10. Balogh Z., Boldogné Cs. M., Borbás I., Bugarszki M., Jakab Zs., Kovács E., Kovácsné K. J., Lakó E., Simkó K., Tóthné F. Gy., Vártok J.(szerk.): Az ápolás helyzete Magyarországon. Egészségügyi Szakképző és Továbbképzó Intézet, 2008. 11. H.-M. Hasselhorn, B. H. Müller, P. Tackenberg: NEXT Scientific Report; July 2005, Univ. of Wuppertal.

12. A. Siket Ujváriné; M. Zrínyi, H. Tóth, I. Szögedi, I. Rimar Zékányné, J. Betlehem: The role of faculty and clinical practice in predicting why nurses graduate in Hungary: Nurse Education Today - közlésre elfogadva 2010.04.26.

13. A. Siket ujváriné, M. Zrínyi, H. Tóth, I. Szögedi; I. Rimár Zékányné, J. Betlehem: Intent to stay in nursing: internal and external migration in Hungary, Journal of Clinical Nursing - köz-lésre elfogadva 2010.05.10. 
14. Ujváriné Siket A., Zrínyi M., Betlehem J., Zékányné Rimár I., Tóth H., Takács P., V. Tothová: Pályaválasztás, ápolói tanulmányok, ápolói munka, pályaelhagyás és migráció vizsgá-lata a magyarországi és csehországi ápoló hallgatók körében. Fôiskolát és Egyetemet végzett Ápolók IX. Országos Kongresszusa, Absztraktgyứjtemény. 2010.

15. KSH Egészségügyi Statisztikai Évkönyv, 2008.

16. Ketskeméty L., Izsó L.: Bevezetés az SPSS programrendszerbe. ELTE, Eötvös Kiadó, Buda-pest, 2005.

17. J. J. Albright, H. M. Park: Confirmatory Factor Analysis using Amos, LISREL, Mplus, SAS/STAT CALIS*. University Information Technology Services Center for Statistical and Mathematical Computing Indiana University, 2009.

Dr. Takács Péter: fóiskolai docens

Dr. Siket Adrienn: fôiskolai adjunktus

Debreceni Egyetem, Egészségügyi Kar, Nyíregyháza, 4400, Sóstói út 2-4. 